\title{
Fluctuations in distribution and patterns of individual range use of northern bottlenose whales
}

\author{
Sascha K. Hooker*** , Hal Whitehead, Shannon Gowans, Robin W. Baird ${ }^{* * *}$ \\ Department of Biology, Dalhousie University, Halifax, Nova Scotia, B3H 4J1, Canada
}

\begin{abstract}
This study investigated the pattern and scale of distribution, movements and range use of the northern bottlenose whale Hyperoodon ampullatus above a submarine canyon, the Gully, off eastern Canada between 1988 and 1998. Locations and individual identification photographs were collected during encounters with whales. Whales showed a discrete distribution within the canyon associated with water depth (500 to $1500 \mathrm{~m}$ ) and relatively steep topography. Encounter rate and distribution showed some variation between years. Changes in distribution were observed toward the north or south of the canyon, probably a consequence of changes in prey distribution. Individual whales within the canyon displaced 4 to $5 \mathrm{~km}$ over $24 \mathrm{~h}$, with negligible further increase in displacement over time scales up to $20 \mathrm{~d}$ (their approximate residency period). Short-term VHF radio-tracking of 5 individuals provided an independent source of movement data, showing displacements of approximately $2 \mathrm{~km}$ in $1 \mathrm{~h}$ and 5 to $10 \mathrm{~km}$ in $1 \mathrm{~d}$. The relative lack of movement observed for these whales supports the hypothesis that the canyon contains a profitable and localized food source. Movements of whales best fit a model of short-term residence within ranges of approximately $25 \mathrm{~km}^{2}$, although the range size of mature males was smaller than that of females and immature males. Photoresightings were also used to investigate variation in the positions of individual whales within the Gully. Within years, individuals showed some separation of ranges associated with periods of high whale abundance, but there was no separation between different age-sex classes. Between years, mature males showed consistent spatial orientations relative to each other, suggesting preferred locations possibly related to mating opportunities.
\end{abstract}

KEY WORDS: Foraging ecology $\cdot$ Cetacean $\cdot$ Submarine canyon $\cdot$ Movements $\cdot$ Range $\cdot$ Territoriality

\section{INTRODUCTION}

Analysis of distribution and movement patterns is critical to understanding the role of an animal in its environment, and allows insight into both its evolutionary development and its ecological behaviour patterns. Data from individual movements can provide details on spatial use, territoriality, and residency (White \& Garrott 1990), in addition to patterns of resource dis-

\footnotetext{
*E-mail: s.hooker@st-andrews.ac.uk

Present addresses:

** Sea Mammal Research Unit, University of St Andrews, St Andrews, Fife, KY16 8LB, United Kingdom

${ }^{* * *}$ National Marine Fisheries Service, NOAA, 101 Pivers Island Road, Beaufort, North Carolina 28516, USA
}

persion and the profitability of foraging (Brown \& Orians 1970, Whitehead 1996, Jaquet \& Whitehead 1999). Thus, the ranging behaviour of animals may have implications for a wide diversity of behavioural and life-history traits, such as foraging strategies, predator defences, group-living, mating systems, social structures and even communication (Geist 1974, Emlen \& Oring 1977, Macdonald 1983, Ostfeld 1990).

The beaked whales (Ziphiidae) are probably the least known group of large mammals, primarily due to their offshore nature and long dive durations. The Gully, a submarine canyon off eastern Canada (see Fig. 1), has been identified as a region of high abundance of the northern bottlenose whale Hyperoodon ampullatus, which shows a strong distributional preference for this region (Hooker et al. 1999). Its reliable distribution 
in this area has facilitated research on this population (Whitehead et al. 1997a,b). Individuals appear to use the Gully for foraging, making dives to depths of $>1000 \mathrm{~m}$ to, or near to, the sea floor (Hooker \& Baird 1999). A population of about 130 individuals uses the area (Gowans et al. 2000a), and many of the same individuals are found in the Gully at different times of the year (Whitehead et al. 1997b). However, recent results suggest that whales are continually entering and leaving the area, remaining within the Gully for an average of $20 \mathrm{~d}$ at a time (Gowans et al. 2000a). Investigations of variation in their distribution, movements and range use can thus provide details of the behaviour and ecology of these whales while in the Gully.

Movement has both spatial and temporal components, but many analytical techniques tend to focus on either one or the other: spatially investigating range use, identifying hotspots, or calculating home-range estimates, or temporally investigating the rate of movement. An alternative method of movement analysis, which encompasses both the spatial and temporal nature of movement, is diffusion approximation (Turchin 1998). The diffusion rate $(D$, the temporal rate of spatial population spread) has advantages over more standard measures of movement such as mean distance moved (Turchin 1998). When animals are tracked and their locations are recorded, the diffusion rate can be estimated from:

$$
\hat{D}=\frac{\sum l_{i}^{2}}{4 \sum t_{i}}
$$

where $l_{\mathrm{i}}$ is the distance and $t_{\mathrm{i}}$ is the time interval between fixes (Turchin 1998). Following from this, a useful analytical approach for the analysis of movement is to plot squared displacement against time (Turchin 1998). Qualitatively different movement patterns, such as directed (straight-line) movement, random movement, or movement within a discrete range, result in different expected curve shapes. This method of analysis can be applied to radio-tracking data and to individual identification data, and will be used here to compare the two. One of the problems with photoidentification is that data are often collected haphazardly in space and time, i.e., sampling is neither uniform nor random. If the probability that an animal is re-identified is dependent on its movement; for example, if sampling does not cover the entire habitat, then a plot of displacement squared against time will be misleading (Turchin 1998). Whitehead (2001) has shown how maximum likelihood methods can be used, incorporating the photographic identifications as a measure of the sampling effort, to generate corrected movement statistics.

This paper examines the distribution and movements of northern bottlenose whales in the Gully, and relates these to what is known of the foraging behaviour of this species. The ranging behaviour observed raises further questions concerning the relative locations of individual ranges. The spatial range use of different age-sex classes is therefore examined to reveal any social or ecological differences in spatial patterning.

\section{METHODS}

Research was conducted in the Gully, off eastern Canada (approximately $44^{\circ} \mathrm{N}, 59^{\circ} \mathrm{W}$ : Fig. 1) between 1988 and 1998, primarily from a 10 to $12 \mathrm{~m}$ auxiliary sailing vessel. The amount of research effort each year varied between a few days (1991 and 1992), or a few weeks (1993 to 1995), to a few months (1988 to 1990, 1996 to 1998), with the majority of research effort occurring during the summer months (June to August). During daylight hours, the Gully area was searched in a non-systematic manner for the northern bottlenose whale Hyperoodon ampullatus. Location data were recorded using radio and satellite positioning. A Loran (SeaPort Loran-C) was used from 1988 to 1992 and GPS (Trimble Transpack or Garmin 65 Global Navigator) from 1993 to 1997. Loran data were accurate to approximately $400 \mathrm{~m}$ and GPS data to approximately $200 \mathrm{~m}$. The bearing and estimated distance of whales from the research vessel were noted and used to calculate each encounter position. A new encounter was defined as a whale or group of whales first spotted after at least 10 min without any whales in view. This definition was tested during VHF radio-tracking of

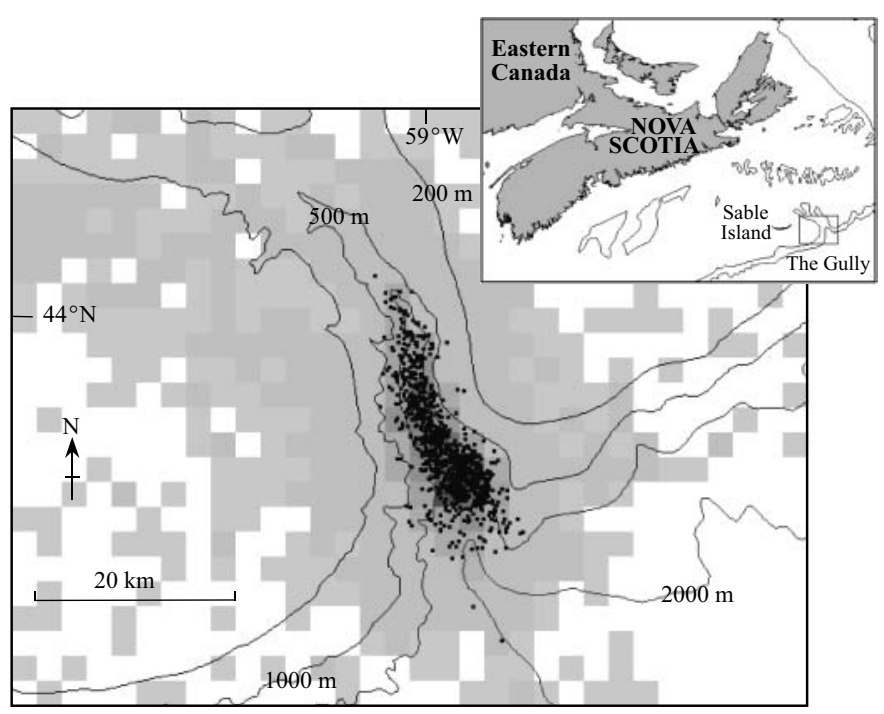

Fig. 1. Hyperoodon ampullatus. Positions of encounters with bottlenose whales are shown in relation to the bathymetry of the Gully submarine canyon and to the distribution of search effort (shaded grid cells) in the area. Inset: location of the Gully relative to eastern Canada 
whales, whereby, if whales dived for longer than $10 \mathrm{~min}$ they were generally very difficult to relocate visually, but could be tracked by radio-signals. For any study of cetacean distribution, effort (i.e., a measure of the locations searched) is crucial in correcting the bias present in encounter locations (e.g., Kenney \& Winn 1987, Reilly 1990), especially when a systematic or randomly determined search pattern is not used. Here we used the hourly position of the research vessel as our measure of effort, and recorded the differences in encounter rate (number of encounters/number of hours of effort) among years and defined regions in the Gully.

A digitized bathymetric vector map of the Gully region (Seabed Exploration Associates, Halifax, Canada) was used to interpolate depth for each $500 \times 500 \mathrm{~m}$ cell of the region using the GIS software IDRISI. Depth values were used to calculate slope values for each cell (calculated as the maximum slope around each cell from the depth difference between it and neighbouring cells). These depth and slope values were then assigned to encounters and hourly search positions. A Kolmogorov-Smirnov (K-S) goodness-of-fit test was used to test the hypothesis that the depth and slope of the encounter data had the same distribution as those of the effort data.

Photo-identification. During each encounter, whales were approached to within 5 to $15 \mathrm{~m}$ and photographs were taken of the dorsal fin and surrounding flank area. A catalogue of identified individuals was set up and maintained (Gowans \& Whitehead 2001). Whenever possible, photographs of the melon (forehead) profile of a whale were taken in conjunction with a photograph of its dorsal fin. Bottlenose whales are sexually dimorphic in head shape, and these photographs were later used to assign 1 of 3 age-sex classes: female/immature male, subadult male, or mature male (Gray 1882, Gowans et al. 2000b).

Movements between all photo-resightings (1988 to 1997) were used to calculate diffusion rates over a range of time intervals using the SOCPROG suite of Matlab programs (written by $\mathrm{H}$. Whitehead; available from http://is.dal.ca/ whitelab/), either directly (using Eq. 1) or using likelihood techniques that estimated the diffusion rate by maximizing the likelihood of the patterns of identifications and re-identifications in space and time using Poisson error (Whitehead 2001). Three measures of movement were calculated with time interval: estimated diffusion rate, mean-squared displacement, and root mean-squared (RMS) displacement (see Eq. 1). Standard errors for these parameter estimates were obtained by jackknifing, omitting consecutive $10 \mathrm{~d}$ (for analyses over years) or $10 \mathrm{~h}$ (for analyses over days) periods in turn (Efron \& Gong 1983).
Three models were fitted to the mean-squared displacement $\left(x^{2}\right)$ versus time $(t)$ data to investigate movement type: random movement: $x^{2}=k t$ (linear); directional movement: $x^{2}=k t^{\left(b^{2}+1\right)}$ (upward curve); movement within a discrete range: $x^{2}=k \cdot \frac{t}{t+a^{2}}$ (asymptote, $k$, gives an estimate of the extent of the range).

As some of the markings used to identify individuals are known to change with time, the quality of the photo and the distinctiveness of an individual's marks will affect the likelihood of it being re-identified over long time scales (Gowans \& Whitehead 2001). For time scales $>1 \mathrm{yr}$, data were restricted to comparisons of only reliably-marked individuals, i.e., those with mark types which do not change between years, with both left and right sides identified by good-quality photographs (see Gowans \& Whitehead 2001). However, over time scales $<1 \mathrm{yr}$, all identifications of all individuals were used (since all whales can be accurately re-identified within a single field season).

Radio-tracking. Between 1996 and 1998, suctioncup attached radio-transmitters (148 and $164 \mathrm{MHz}$ ) were deployed on northern bottlenose whales in the Gully (as described in Hooker \& Baird 1999). Once tags were attached, we attempted to maintain close proximity $(<500 \mathrm{~m})$ to the tagged whale, and positions were recorded from GPS. VHF radio-signals do not transmit through seawater and so localization of signals could only be attempted when the tag cleared the water surface as the whale surfaced to breathe. Tracking was conducted using a directional hand-held antenna.

Individual ranges. The positions of all photographically identified whales (limited to those with reliable marks and using only those identifiable from both left and right sides) were used to investigate differences in ranging patterns between individuals. Since individual positions were likely to be autocorrelated within each day, these data were reduced to the following datasets: (1) the mean position of each individual in each year; (2) the mean position of each individual each day. The first dataset was used to test for overall differences between years in positions of individuals, and differences between age-sex classes in positions within each year. The second dataset was used to test for individual differences in location within each year. In addition, this test was also repeated for each age-sex class in turn, to determine whether individuals in some agesex classes separated themselves spatially while others did not. All tests were performed using MANOVAs (with latitude and longitude as dependent variables).

Because individual locations varied according to year, and individuals appeared to separate themselves spatially, the presence of consistent relative spatial differences between individuals was also investigated. The 
mean position of each individual in each year was used to calculate the overall mean yearly position for all whales. The variation of each individual position from this was then used to investigate changes in relative positioning between individuals of each age-sex class for all years.

\section{RESULTS}

\section{Variation in abundance and distribution}

Investigation of the influence of sea conditions on sighting rate showed a dramatic reduction in sightings above Beaufort 4, and data were therefore restricted to those collected in sea conditions better than this. Abundance of Hyperoodon ampullatus varied by a factor of $\sim 2$, and significantly, between years (Table 1; G-statistic for goodness of fit 33.9, $n=9, p<0.001$ ). There appears to have been a noticeably lower sighting rate in 1988; however, this was essentially a pilot research year, and effort expended outside of the canyon area probably resulted in an underestimation of whale presence. Relatively low abundances were recorded in 1994 and 1995 (62 and $74 \%$ of the overall mean respectively).

A direct comparison of sightings to effort showed that depth and slope for encounters were significantly different from those for search locations (depth K-S value $0.213, \mathrm{p}<0.001$; slope K-S value 0.142 , $\mathrm{p}<0.001$; Fig. 2). Depth and slope were correlated $(r=0.268)$, and the interaction between depth, slope and encounters or search effort was significant (loglinear model, $\mathrm{p}<0.001$ ). The relative importance of depth appeared to be greater than that of slope, however. (The general linear model for slope within depth categories was not significant $[p=0.073]$, whereas that for depth within different slope categories was significant [ $p=0.001]$.)

Variation in sighting locations between years appeared to occur primarily along the north-south axis of

Table 1. Hyperoodon ampullatus. Interannual variation in sighting rate, calculated only for good sea conditions (Beaufort $<4$ ). Assuming independent sightings, approximate standard errors were calculated as (sighting rate) $/ \sqrt{ }$ (number of sightings)

\begin{tabular}{|ccccc|}
\hline Year & $\begin{array}{c}\text { No. of } \\
\text { sightings }\end{array}$ & $\begin{array}{c}\text { No. of } \\
\text { search hours }\end{array}$ & \multicolumn{2}{c|}{ Sighting rate } \\
Mean & (SE) \\
\hline 1988 & 7 & 30 & 0.23 & $(0.088)$ \\
1989 & 57 & 170 & 0.34 & $(0.044)$ \\
1990 & 125 & 238 & 0.53 & $(0.047)$ \\
1993 & 54 & 78 & 0.69 & $(0.094)$ \\
1994 & 25 & 84 & 0.29 & $(0.060)$ \\
1995 & 11 & 31 & 0.35 & $(0.110)$ \\
1996 & 172 & 330 & 0.52 & $(0.040)$ \\
1997 & 157 & 304 & 0.59 & $(0.041)$ \\
1998 & 107 & 181 & 0.53 & $(0.057)$ \\
\hline
\end{tabular}
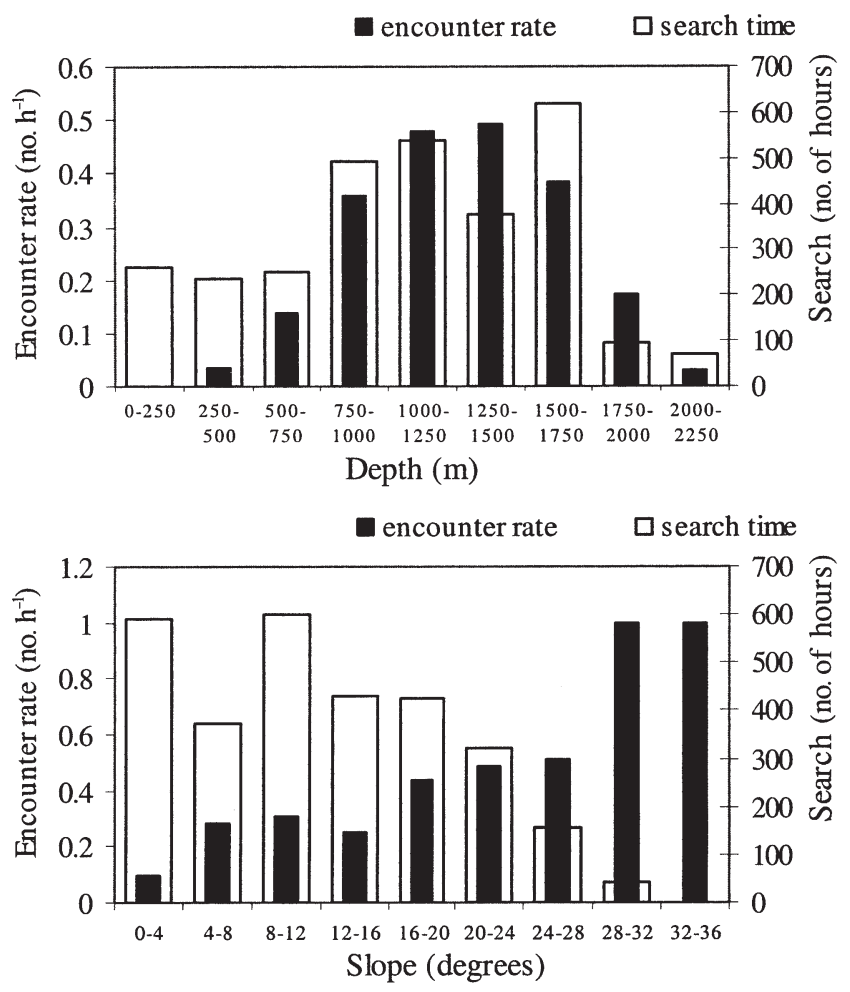

Fig. 2. Hyperoodon ampullatus. Variation in bottlenose whale encounter rate (number of encounters per hour search effort) as a function of depth (upper graph) and slope (lower graph). Search effort (time) is shown for each depth or slope category

to provide indication of confidence in sighting rate

the canyon (Fig. 3). Whales were distributed towards the mouth (south end) of the Gully in 1989 to 1993, towards the head (north end) in 1994 to 1996, fairly evenly throughout the Gully in 1997, and towards the head in 1998.

\section{Movement analysis using photo-identification data}

A total of 682 individuals have been identified in the Gully bottlenose whale photo-catalogue, but many of these are likely to be duplicates between left and right side identifications and between separate years. Of these, 113 individuals possessed mark types which do not change between years (see Gowans \& Whitehead 2001 for details), and many of these were re-identified over multiple years. For example, of the 15 reliably marked individuals identified in 1988, at least one has been photographed during every year since then.

Over the time scale of the residency period recorded for bottlenose whales in the Gully (Gowans et al. 2000a), displacements showed an initial increase and then levelled-off with increasing time interval (Fig. 4). The likelihood method of calculation (detailed in Whitehead 2001) gave almost identical results (Fig. 4), 


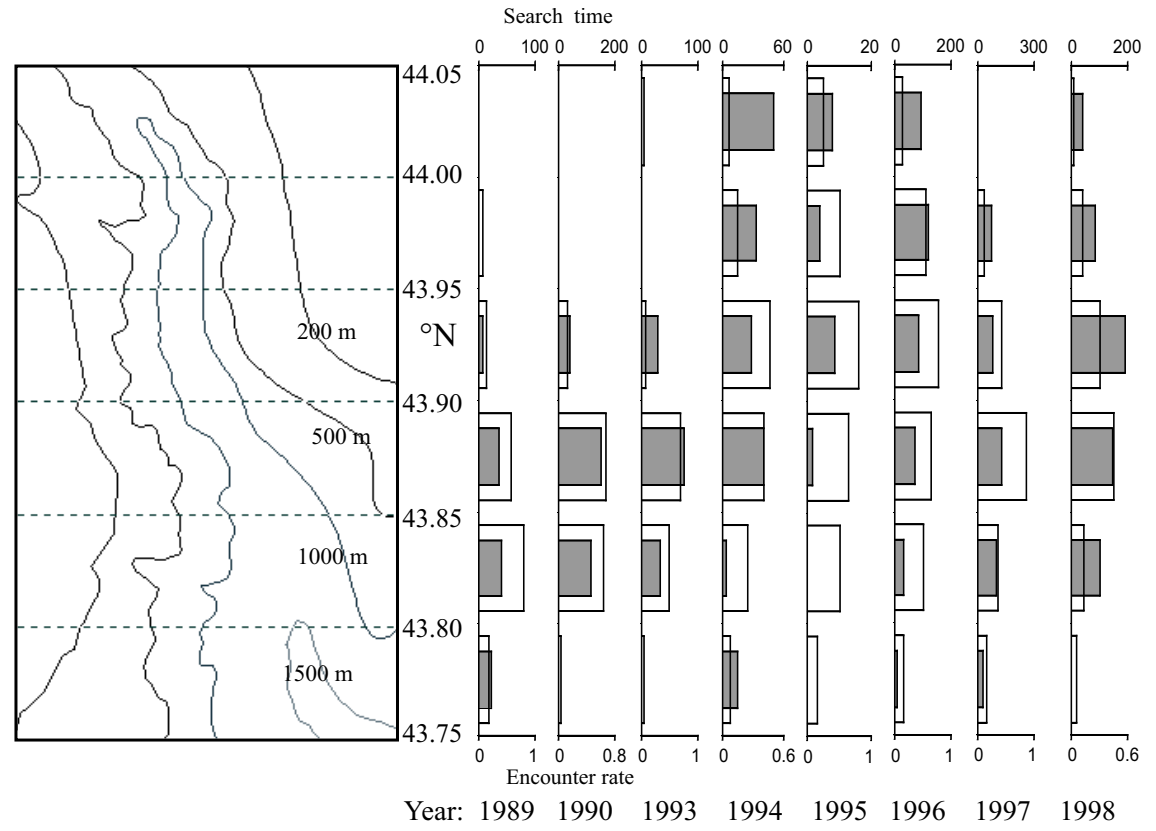

Fig. 3. Hyperoodon ampullatus. Yearly plots of variation in encounter rate (no. $\mathrm{h}^{-1}$ ) and search effort (no. of hours) along the north-south gradient through the Gully. Map on left shows bands along the north-south axis of the Gully for which encounter rate and search effort were calculated; graphs on right show yearly variation in encounter rate (shaded) and the distribution of search effort (unshaded) for these areas
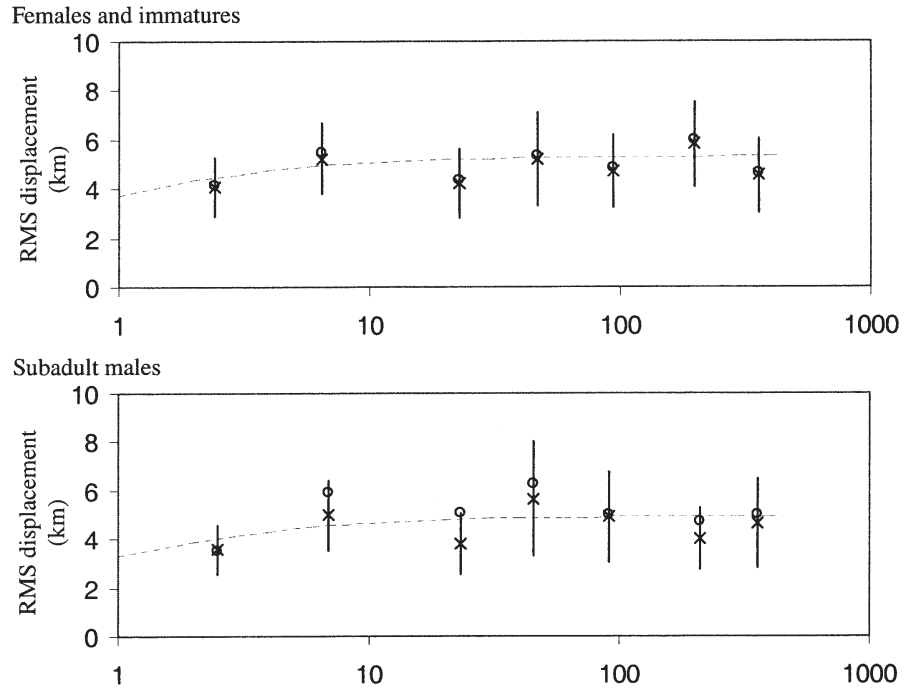

Mature males

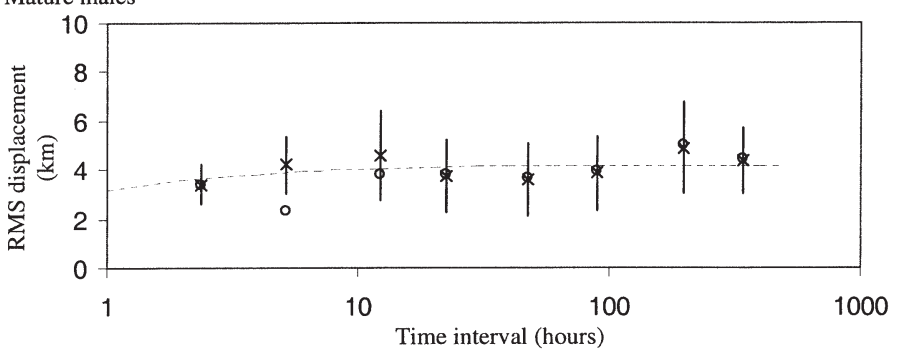

Fig. 4. Hyperoodon ampullatus. Root mean-squared (RMS) displacement calculated from resightings of individuals over time lags of $2 \mathrm{~h}$ to $20 \mathrm{~d}$ for different age-sex classes. $\mathrm{x}$ : movement estimates calculated directly (using Eq. 1); bars: jackknifed standard errors for these estimates; dashed lines: fit of the discrete range model to these data; o: movement estimates calculated using likelihood technique (see 'Methods' for details) demonstrating that the observed pattern of bottlenose whale resightings was similar to that of search effort, i.e., the probability of sampling an individual was relatively constant over the area in which that individual was likely to be found, given that the individual was within the Gully. The discrete range model gave the best fit for movements pooled for all individuals (Table 2). Movements were approximately 3 to $4 \mathrm{~km}$ over 2 h (Fig. 4). Between different age-sex classes, females and immatures appeared to have slightly larger ranges than subadult males, which in turn were slightly larger than those of mature males (Fig. 4, Table 3). There were minor differences in movements between years, but small sample sizes prohibited investigation in greater detail (Table 3). The orientation of the Gully and distribution of whales within it (Fig. 1) suggested that whales might be moving primarily northsouth within the Gully. This was investigated by conducting 1-dimensional analysis using the latitudinal or the longitudinal component of position data in turn. Over periods of hours to days there was greater displacement north-south $(3.5 \mathrm{~km})$ than east-west $(2.2 \mathrm{~km}$, Table 3$)$.

\section{Radio-tracking}

Five tags were deployed on northern bottlenose whales for intervals ranging from 2.5 to $28 \mathrm{~h}$. Various problems were encountered in attempting to follow the tagged individuals. Occasionally the suction-cup attachment of the tags would migrate down the body of the whale preventing the emergence of the antenna during surfacing. The long-duration dives of bottlenose 
Table 2. Hyperoodon ampullatus. Best-fit of models to movement data (within $20 \mathrm{~d}$ time scale) for all individuals pooled for all years. R-squared is shown for non-linear regression of data to model (see 'Methods' for details)

\begin{tabular}{|llcl|}
\hline & Model & R-squared & Model terms \\
\hline Random movement & $x^{2}=k t$ & 0.118 & Did not converge \\
Directed movement & $x^{2}=k t^{\left(b^{2}+1\right)}$ & 0.118 & Did not converge \\
Discrete range & $x^{2}=k \cdot \frac{t}{t+a^{2}}$ & 0.282 & $k=25.00, a=1.08$ \\
& & & \\
\hline
\end{tabular}

\section{Individual ranges}

As observed for encounter locations, there were significant differences between years in the average location of individuals (MANOVA: $F=29.5, \mathrm{p}<0.001,9 \mathrm{yr})$. Variation, calculated as the square root of the summed variances in latitude and longitude, was approximately $5 \mathrm{~km}$ between years. Within each year, the positions of individuals of different age-sex classes showed no significant differences (MANOVAs for each year: $p>0.05$ ).

Within years, there appeared to be some separation between individuals in the Gully in terms of preferred ranges (Table 4). Individuals generally appeared to show some range separation during 1990, 1996 and 1997. This effect was also seen between individuals within each age-sex class (Table 4 ). Since these were the years of greatest field effort (Table 1), they had the greatest power to detect significant differences. However, these were also the years of longest field effort, so in order to check that a significant individual effect was not in fact caused by differences in sightings between months (e.g., some whales being sighted earlier and further south, some later and further north), the test was repeated including month as a factor. Although for 2 years $(1990,1997)$ month had a significant effect $(\mathrm{p}<0.05)$, there was a significant individual effect for all 3 years even when month was included as a factor $(\mathrm{p}<0.05)$.

There were significant differences between individuals in relative spatial orientation between years (variations from the mean yearly location, MANOVA: $F=1.263, \mathrm{p}=0.026)$. Significant differences were

Table 3. Hyperoodon ampullatus. Rates of movement calculated for different sub-samples of the dataset: for all data (all years, all individuals), for individuals categorized by age-sex class, for years with greatest field effort, and for latitude and longitude separately (all years, all individuals). Diffusion rates and squared displacement are means (SE); best-fit model was discrete range (level of asymptote, $k$, mean [SE] is shown). IDs: identifications; -: not shown (insufficient data to conduct model fitting)

\begin{tabular}{|c|c|c|c|c|c|}
\hline Data subset & $\begin{array}{l}\text { Total } \\
\text { IDs }\end{array}$ & $\begin{array}{c}\text { No. of } \\
\text { encounters }\end{array}$ & $\begin{array}{l}2 \mathrm{~h} \text { diffusion } \\
\text { rate }\left(\mathrm{km}^{2} \mathrm{~h}^{-1}\right)\end{array}$ & $\begin{array}{c}\text { Daily squared } \\
\text { displacement }\left(\mathrm{km}^{2}\right)\end{array}$ & $\begin{array}{c}\text { Discrete range } \\
\text { model asymptote } k\left(\mathrm{~km}^{2}\right)\end{array}$ \\
\hline All data (1988-1997) & 682 & 597 & $1.41(0.25)$ & $17.34(4.02)$ & $25.00(2.87)$ \\
\hline \multicolumn{6}{|l|}{ Age-sex classes } \\
\hline Females/immatures & 107 & 94 & $1.69(0.59)$ & $20.07(7.41)$ & $28.37(4.91)$ \\
\hline Subadult males & 25 & 61 & $1.28(0.44)$ & $11.76(7.45)$ & $24.30(3.43)$ \\
\hline Mature males & 33 & 60 & $1.20(0.29)$ & $16.25(9.28)$ & $17.53(2.34)$ \\
\hline \multicolumn{6}{|c|}{ Years of greatest field effort } \\
\hline 1989 & 170 & 11 & $1.08(0.41)$ & $18.63(9.00)$ & - \\
\hline 1990 & 260 & 25 & $1.39(0.72)$ & 7.96 (2.09) & - \\
\hline 1996 & 136 & 26 & $0.88(0.42)$ & $25.60(8.08)$ & - \\
\hline 1997 & 140 & 30 & $0.72(0.18)$ & $11.03(1.96)$ & - \\
\hline \multicolumn{6}{|c|}{ Single dimension movements } \\
\hline Latitude only & 682 & 597 & $1.53(0.36)$ & $12.15(2.47)$ & - \\
\hline Longitude only & 682 & 597 & $0.92(0.30)$ & 4.70 (1.09) & - \\
\hline
\end{tabular}




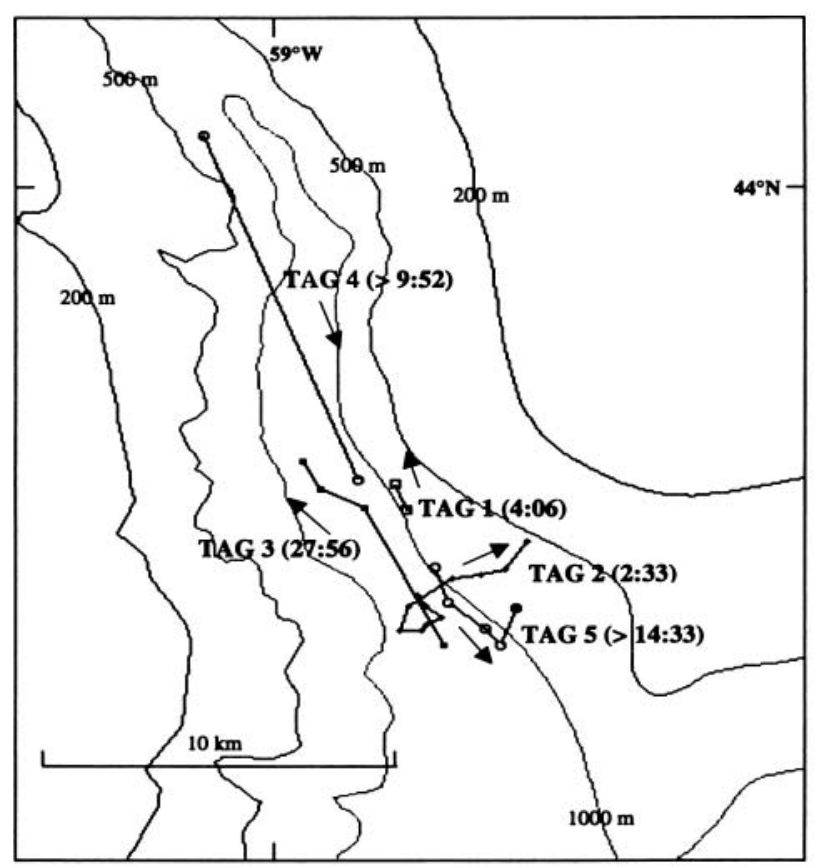

Fig. 5. Hyperoodon ampullatus. Movements of radio-tracked individuals. Duration (h:min) of each tag attachment is shown in parentheses; minimum duration is shown for Tags 4 and 5, which were not recovered

found between the relative locations of mature males but not between those of other age-sex classes (Table 5). This separation between mature males was based on the consistent orientation of individuals relative to each other, whereas the separation between females/immatures and between subadult males was not of consistent orientation (e.g., always to the north or south of the average position). Plots of individual male sightings for the years of most field effort show this tendency toward consistent relative location from year to year (Fig. 6). For example, male \#950 was observed to the north of other males in 1996 and 1997, whereas \#480 had a central location in relation to other males.

\section{DISCUSSION}

On a broad scale, the northern bottlenose whale Hyperoodon ampullatus (and other beaked whales) shows a clear preference for deep water (Benjaminsen 1972, Benjaminsen \& Christensen 1979). However, small-scale variation in distribution and individual movements have not previously been examined. The localised distribution of these whales above the Gully submarine canyon therefore presents a unique opportunity to examine the variation in their use of such an area. A strong relationship between bottlenose whale distribution and the bathymetric features depth and
Table 4. Hyperoodon ampullatus. Results of MANOVAs testing for differences between all individuals in sighting positions (i.e., Did individuals have consistent locations relative to mean location?) and within each age-sex class (i.e., Did individuals within particular age-sex classes have consistent positions relative to mean position of their age-sex class?). Dependent variables were latitude and longitude; independent categorical variable was individual. Variation was calculated as the square root of variance in latitude plus longitude for relevant individuals. $p$ values in bold-face: significant

\begin{tabular}{|c|c|c|c|c|}
\hline Year & $\mathrm{n}$ & Variation $(\mathrm{km})$ & $F$-statistic & $\mathrm{p}$ \\
\hline \multicolumn{5}{|c|}{ All individuals } \\
\hline 1989 & 25 & 1.61 & 0.999 & 0.489 \\
\hline 1990 & 50 & 2.08 & 1.468 & 0.010 \\
\hline 1993 & 10 & 2.45 & 1.595 & 0.114 \\
\hline 1994 & 6 & 2.36 & 0.665 & 0.737 \\
\hline 1996 & 29 & 4.77 & 1.947 & 0.001 \\
\hline 1997 & 31 & 2.96 & 1.694 & 0.008 \\
\hline \multicolumn{5}{|c|}{ Females/immatures } \\
\hline 1989 & 6 & 1.39 & 0.790 & 0.640 \\
\hline 1990 & 14 & 1.90 & 2.052 & 0.008 \\
\hline 1993 & 6 & 2.72 & 2.365 & 0.049 \\
\hline 1996 & 7 & 3.31 & 1.677 & 0.123 \\
\hline 1997 & 13 & 2.24 & 2.360 & 0.005 \\
\hline \multicolumn{5}{|c|}{ Subadult males } \\
\hline 1989 & 5 & 1.15 & 0.962 & 0.494 \\
\hline 1990 & 11 & 1.90 & 1.717 & 0.049 \\
\hline 1996 & 5 & 3.42 & 2.011 & 0.077 \\
\hline 1997 & 3 & 2.57 & 1.150 & 0.418 \\
\hline \multicolumn{5}{|c|}{ Mature males } \\
\hline 1989 & 4 & 1.54 & 0.462 & 0.830 \\
\hline 1990 & 10 & 2.04 & 2.872 & 0.003 \\
\hline 1996 & 8 & 3.10 & 2.446 & 0.021 \\
\hline 1997 & 6 & 1.52 & 1.235 & 0.341 \\
\hline
\end{tabular}

Table 5. Hyperoodon ampullatus. Results of MANOVA testing individual consistency in relative location. Differences between yearly mean individual positions were tested for individuals within each age-sex class. Dependent variables were $\Delta$ latitude and $\Delta$ longitude; independent categorical variable was individual

\begin{tabular}{|lccc|}
\hline & $\mathrm{n}$ & $F$-statistic & $\mathrm{p}$ \\
\hline Females/immatures & 31 & 0.896 & 0.679 \\
Subadult males & 15 & 0.852 & 0.669 \\
Mature males & 18 & 1.850 & 0.015 \\
\hline
\end{tabular}

slope was also observed in this study (Fig. 2). Even at this relatively small scale, deep water and relatively steep topographic features therefore also appear to drive their distribution.

While in the Gully, bottlenose whales appear to spend the majority of their time foraging (Hooker \& Baird 1999). Analysis of the stomach contents of stranded individuals and the analysis of fatty acids and stable isotopes in the blubber and skin of whales sam- 

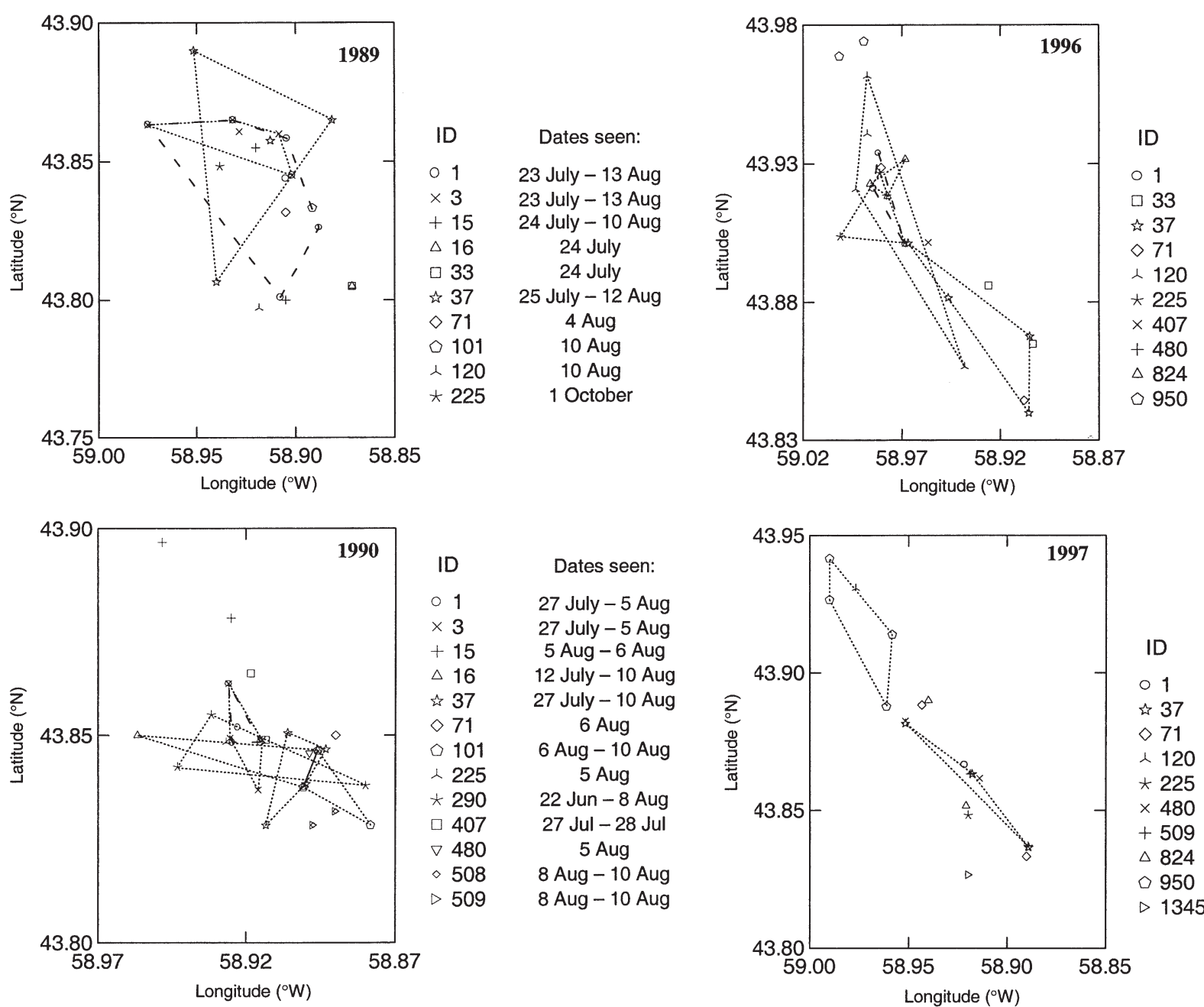
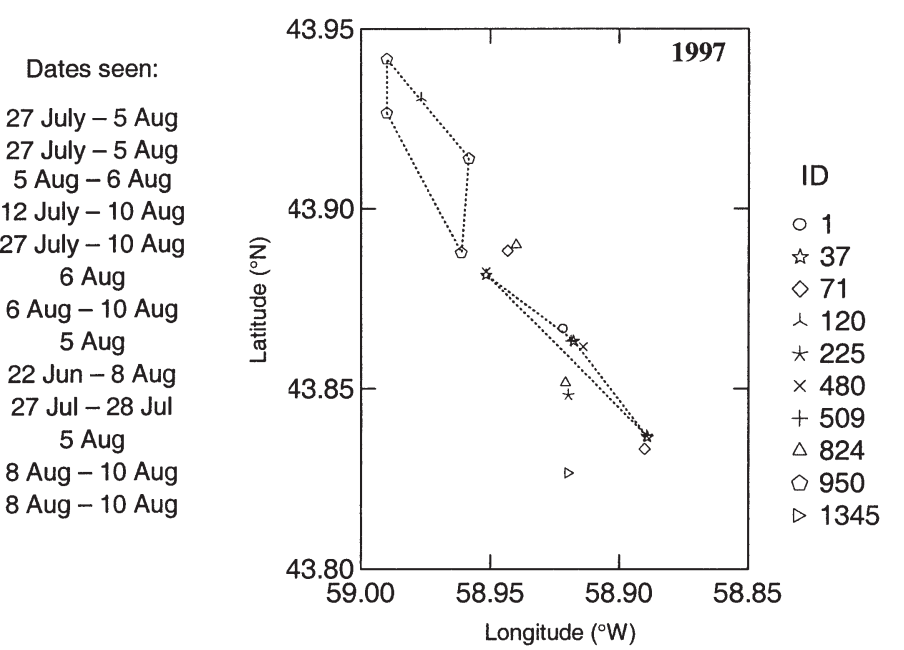

Dates seen:

29 July -4 Aug

9 Jun

9 Jun -27 Aug

29 July -27 Aug

9 Jun -22 Jun

$29 \mathrm{Jul}-1$ Aug

22 Aug

1 Aug

1 Aug -4 Aug

19 Jun

Fig. 6. Hyperoodon ampullatus. Male ranges for years of highest number of sightings. Mean daily positions of individuals (ID) are shown. First and last dates that each individual was seen illustrate overlap in time periods of sightings. Lines join locations of individuals seen on $\geq 3 \mathrm{~d}$

pled in the Gully suggests that their primary prey are adult squid of the genus Gonatus (Hooker et al. 2001). The abundance and distribution of bottlenose whales in the Gully (Figs. 1 \& 2) and changes observed between years (Table 1, Fig. 3) are therefore likely to be due to variation in the abundance and distribution of their prey. Adult Gonatus spp. are found in deep water at the continental shelf edge (Kristensen 1983), but the relationship between their distribution and changes in environmental conditions is unknown. Co-incident with variation in bottlenose whale distribution (Fig. 3) were shifts in the Gulf Stream (such as the northerly shift observed between 1994 and 1996: Taylor et al. 1998). It is quite plausible that an event such as this may have caused changes in sea-floor currents or temperature stratification, causing the movement of squid prey further north within the Gully.

Over small temporal scales (less than their average residency period of $20 \pm 10 \mathrm{~d}$ : Gowans et al. 2000a), net movements of bottlenose whales in the Gully were small. Photo-resightings showed mean displacements of 3 to $4 \mathrm{~km}$ over $2 \mathrm{~h}$ and 4 to $5 \mathrm{~km}$ over $1 \mathrm{~d}$ (Fig. 4) within a range encompassing 15 to $30 \mathrm{~km}^{2}$ (Table 3 ). Such net daily movements are relatively small compared to those of other offshore oceanic cetaceans (e.g., the approximately $50 \mathrm{~km}$ daily displacements of the sperm whale Physeter macrocephalus [Whitehead 2001] and the pantropical spotted dolphin Stenella attenuata [Perrin et al. 1979]). Such small-scale movements are more typical of coastal species (e.g., the bottlenose dolphin Tursiops truncatus: Mate et al. 1995). Movements of sperm whales over periods of days were found to correlate inversely with their foraging success (Whitehead 1996, Jaquet \& Whitehead 1999). Similarly, since the primary activity previously observed during detailed time-depth recorder deployment on whales in the Gully was foraging (Hooker \& Baird 1999), the small amount of movement shown by these 
whales is also likely to be related to a profitable food source in this area.

Since we did not sample whales at every surfacing for collection of photo-identification data, it could be argued that this pattern of movement within a 20 to $25 \mathrm{~km}^{2}$ area reflects the movements of the study vessel, rather than the movements of the whales. There are 3 reasons why we do not believe this was the case: (1) The distribution of bottlenose whales within the Gully appears to be fairly isolated, despite periodic search effort outside the core area (Hooker et al. 1999, and present Fig. 1). (2) Whales have residency periods of approximately $20 \mathrm{~d}$ within the Gully (Gowans et al. 2000a), and therefore measurement of movement within this time frame should accurately reflect whale movement within the Gully study area; for periods up to $20 \mathrm{~d}$, the whales appear to have a discrete range within the Gully, much of which they cover in a single day. (3) The agreement between calculations of movement parameters using direct or likelihood methods (which allow for an irregular distribution of effort) suggests that the movement rates calculated were not biased by search effort (Fig. 4).

Results from radio-tracked whales showed a similar scale of movement over time scales of $2 \mathrm{~h}$ (2.5 to $3.5 \mathrm{~km}, \mathrm{n}=3$ ), but greater movements over time scales of $1 \mathrm{~d}$ ( 6 to $13 \mathrm{~km}, \mathrm{n}=2$ ). This presumably reflects individuals leaving the Gully. Our research has focused only on whale movements within the Gully area, and we know almost nothing of how they behave when they leave this area. It has been previously suggested that northern bottlenose whales can move fairly large distances in a short time period. The good condition of a beak of the cephalopod Vampyroteuthis infernalis in the stomach of a northern bottlenose whale stranded in the Faroe Islands suggests that this whale had travelled at least $1000 \mathrm{~km}$ (from more southerly regions where this cephalopod is found) within a few days (Clarke \& Kristensen 1980). Another stranded bottlenose whale (in Hiddensee in the Baltic) contained Gonatus fabricii beaks, and Gonatus (and bottlenose whales) are usually distributed at least $1000 \mathrm{~km}$ away in the Norwegian Sea (Lick \& Piatkowski 1998). Southern bottlenose whales Hyperoodon planifrons live-stranded and caught off South Africa contained squid usually found in the Antarctic and sub-antarctic (Sekiguchi et al. 1993). Likewise, diatoms found on the skin of one of these whales also suggested that it had recently moved into warmer waters (Nemoto et al. 1980).

Individuals within all age-sex classes of whales showed differences in their locations within the Gully during some years (Table 4). The years during which the whales appeared to have preferred ranges coincided with those during which highest whale abundance was recorded (Table 1). These years were also those of the highest number of individuals recorded and the greatest spread of individuals (as reflected by the variation of individual position from the mean: Table 4). Since MANOVAs generally have less power to detect differences with increasing number of groups tested, this separation of ranges does not appear to be an artefact of the number of individuals tested.

If, as the results suggest, individual bottlenose whales are attracted to the Gully because of profitable foraging opportunities there, this raises the question of why they leave again? The answer to this presumably lies in the per capita profitability of foraging. An individual would experience diminishing returns as the number of whales in the Gully increases. Although the Gully may be much richer than another foraging area, as more individuals enter the richer patch, an individual will eventually do better in terms of individual net gain in a poorer patch. An 'ideal free distribution' (IFD) will then result (Fretwell \& Lucas 1970). One of the assumptions of ideal free distribution is that individuals have perfect knowledge of the relative availabilities of resources. However, animals are unlikely to have perfect information and may move between patches in order to make sampling decisions, or for other reasons. Experimenters commonly report movement of animals between patches even after an equilibrium has been reached (see review in Hugie \& Grand 1998). When non-IFD movements are incorporated into an IFD model, the equilibrium will often resemble that for IFD conditions (Hugie \& Grand 1998). Bottlenose whales in the Gully show movements of a discrete-range type, and enter and leave the Gully at variable intervals (average $20 \mathrm{~d}$ : Gowans et al. 2000a), and therefore potentially fit such a model. If this is the case, it suggests that fluctuations in prey density take place over these time scales.

Different age-sex classes of bottlenose whales showed differences in both their movements and range use. The movement of whales within the Gully appears best modelled as a discrete range encompassing an area of approximately $25 \mathrm{~km}^{2}$. However, mature males had slightly smaller range sizes than subadult males, which in turn had slightly smaller ranges than females and immatures (Table 3). Investigation of locations in which the whales were found in the Gully showed little variation between age-sex classes. However, within age-sex classes, mature males showed consistent differences in relative location between years, which were not shown by females and immatures or by subadult males (Table 5). Since both males and females were distributed over the same area, and yet females showed no preference for relative location between years, such relative spatial preference seems unlikely to be related to foraging. Available evidence suggests that male bottlenose whales probably mate during the 
summer in the Gully. Fetus lengths recorded by whalers suggested a loosely defined mating season (with occasional mating year-round) and an approximate $1 \mathrm{yr}$ gestation (Christensen 1973), and, since very young infants have been observed in the Gully during the summer months (Gowans et al. 2001), bottlenose whales are also likely to mate at this time. The relative spatial differences between mature males are therefore more likely to be based on preference for relative spatial locations which provide different mating opportunities as females enter and leave the Gully. Similar stratified movement of individuals, also thought to be due to competitive social interactions between individuals or groups, has been observed among bottlenose dolphins in the Moray Firth, Scotland (Wilson et al. 1997). Conflict between adult male bottlenose whales has been observed in the Gully during the summer, and provides some anecdotal behavioural support for potential competition between males in the Gully (Gowans \& Rendell 1999). However, it does not appear that all individual males are territorial towards each other, as groups of 2 to 3 males have also been observed to form long-lasting coalitions (Gowans et al. 2001).

In conclusion, this work supports previous studies which have noted that northern bottlenose whales show a distributional preference for the Gully area (Reeves et al. 1993, Hooker et al. 1999). Furthermore, the distributional changes between years and small scale of movements noted here support previous observations of diving behaviour (Hooker \& Baird 1999) in suggesting that the primary activity of these whales in the Gully is foraging. However, it appears that males may also be orienting themselves spatially in some form of territoriality, potentially in order to promote mating opportunities. Although many questions remain, it appears that the behavioural ecology of this enigmatic species of whale may be superficially similar to that of many other mammals, with female distribution largely determined by access to resources, while that of males is related to access to females (Davies 1991).

Acknowledgements. This research was funded by the Natural Sciences and Engineering Research Council (NSERC) of Canada, World Wildlife Fund Canada/Canadian Wildlife Service Endangered Species Recovery Fund, the Whale and Dolphin Conservation Society and the Canadian Federation of Humane Societies. Funding for radio-tagging equipment was provided by an NSERC equipment grant and the Keiko Foundation. We are very grateful to the many crew members who have assisted with data collection in the field, particularly to Annick Faucher, who initiated the bottlenose whale photo-identification work. S.K.H. received support for her $\mathrm{PhD}$ research from a Canadian Commonwealth Scholarship; S.G. was supported by an NSERC and an Isaac Walton Killam Scholarship. R.W.B. was supported by an NSERC post-doctoral scholarship. W. D. Bowen, S. J. Iverson, and A. Ottensmeyer, and 3 anonymous referees provided useful suggestions on earlier drafts of this manuscript.

\section{LITERATURE CITED}

Benjaminsen $\mathrm{T}$ (1972) On the biology of the bottlenose whale, Hyperoodon ampullatus (Forster). Norw J Zool 20: 233-241

Benjaminsen T, Christensen I (1979) The natural history of the bottlenose whale, Hyperoodon ampullatus. In: Winn HE, Olla BL (eds) Behaviour of marine animals: current perspectives in research. Plenum Press, New York, p 143-164

Brown JL, Orians GH (1970) Spacing patterns in mobile animals. Annu Rev Ecol Syst 1:239-262

Christensen I (1973) Age determination, age distribution and growth of bottlenose whales, Hyperoodon ampullatus, in the Labrador Sea. Norw J Zool 21:331-340

Clarke MR, Kristensen TK (1980) Cephalopod beaks from the stomachs of two northern bottlenosed whales (Hyperoodon ampullatus). J Mar Biol Assoc UK 60:151-156

Davies NB (1991) Mating systems. In: Krebs JR, Davies NB (eds) Behavioural ecology. An evolutionary approach. Blackwell Scientific Publications, Oxford, p 263-294

Efron B, Gong G (1983) A leisurely look at the bootstrap, the jackknife, and cross-validation. Am Stat 37:36-48

Emlen ST, Oring LW (1977) Ecology, sexual selection, and the evolution of mating systems. Science 197:215-223

Fretwell SD, Lucas HLJ (1970) On territorial behavior and other factors influencing habitat distribution in birds. Acta Biotheor 19:16-36

Geist V (1974) On the relationship of social evolution and ecology in ungulates. Am Zool 14:205-220

Gowans S, Rendell L (1999) Head-butting in northern bottlenose whales (Hyperoodon ampullatus): a possible function for big heads? Mar Mamm Sci 15:1342-1350

Gowans S, Whitehead H (2001) Photographic identification of northern bottlenose whales (Hyperoodon ampullatus): sources of heterogeneity from natural marks. Mar Mamm Sci 17:76-93

Gowans S, Dalebout ML, Hooker SK, Whitehead H (2000a) Reliability of photographic and molecular techniques for sexing northern bottlenose whales (Hyperoodon ampullatus). Can J Zool 78:1224-1229

Gowans S, Whitehead H, Arch JK, Hooker SK (2000b) Population size and residency patterns of northern bottlenose whales (Hyperoodon ampullatus) using the Gully, Nova Scotia. J Cetacean Res Manag 2:201-210

Gowans S, Whitehead H, Hooker SK (2001) Social organization in northern bottlenose whales (Hyperoodon ampullatus): not driven by deep water foraging. Anim Behav 62:369-377

Gray D (1882) Notes on the characteristics and habits of the bottlenose whale (Hyperoodon rostratus). Proc Zool Soc Lond 1882:726-731

Hooker SK, Baird RW (1999) Deep-diving behaviour of the northern bottlenose whale, Hyperoodon ampullatus (Cetacea: Ziphiidae). Proc R Soc Lond Ser B Biol Sci 266:671-676

Hooker SK, Whitehead H, Gowans S (1999) Marine protected area design and the spatial and temporal distribution of cetaceans in a submarine canyon. Conserv Bio 13:592-602

Hooker SK, Iverson SJ, Ostrom P, Smith SC (2001) Diet of northern bottlenose whales inferred from fatty-acid and stable-isotope analyses of biopsy samples. Can J Zool 79: $1442-1454$

Hugie DM, Grand TC (1998) Movement between patches, unequal competitors and the ideal free distribution. Evol Ecol 12:1-19

Jaquet N, Whitehead H (1999) Movements, distribution and feeding success of sperm whales in the Pacific Ocean, over 
scales of days and tens of kilometers. Aquat Mamm 25:1-13 Kenney RD, Winn HE (1987) Cetacean biomass densities near submarine canyons compared to adjacent shelf/slope areas. Contin Shelf Res 7:107-114

Kristensen TK (1983) Gonatus fabricii. In: Boyle PR (ed) Cephalopod life cycles, Vol 1. Species accounts. Academic Press, London, p 159-173

Lick R, Piatkowski U (1998) Stomach contents of a northern bottlenose whale (Hyperoodon ampullatus) stranded at Hiddensee, Baltic Sea. J Mar Biol Assoc UK 78:643-650

Macdonald DW (1983) The ecology of carnivore social behaviour. Nature 301:379-384

Mate BR, Rossbach KA, Nieukirk SL, Wells RS, Irvine AB, Scott MD, Read AJ (1995) Satellite-monitored movements and dive behavior of a bottlenose dolphin (Tursiops truncatus) in Tampa Bay, Florida. Mar Mamm Sci 11:452-463

Nemoto T, Best PB, Ishimaru K, Takano H (1980) Diatom films on whales in South African waters. Sci Rep Whales Res Inst Tokyo 32:97-103

Ostfeld RS (1990) The ecology of territoriality in small mammals. Trends Ecol Evol 5:411-415

Perrin WF, Evans WE, Holts DB (1979) Movements of pelagic dolphins (Stenella spp.) in the eastern tropical Pacific as indicated by results of tagging, with summary of tagging operations, 1969-76. NOAA Tech Rep NMFS SSRF-737

Reeves RR, Mitchell E, Whitehead H (1993) Status of the northern bottlenose whale, Hyperooden ampullatus. Can Field Nat 107:490-508

Reilly SB (1990) Seasonal changes in distribution and habitat

Editorial responsibility: Otto Kinne (Editor),

Oldendorf/Luhe, Germany differences among dolphins in the eastern tropical Pacific. Mar Ecol Prog Ser 66:1-11

Sekiguchi K, Klages N, Findlay K, Best PB (1993) Feeding habits and possible movements of southern bottlenose whales (Hyperoodon planifrons). Proc Natl Inst Polar Res (NIPR) Symp Polar Biol 6:84-97

Taylor AH, Jordan MB, Stephens JA (1998) Gulf stream shifts following ENSO events. Nature 393:638

Turchin P (1998) Quantitative analysis of movement: measuring and modeling population redistribution in animals and plants. Sinauer Associates, Inc, Sunderland, MA

White GC, Garrott RA (1990) Analysis of wildlife radio-tracking data. Academic Press, San Diego, CA

Whitehead H (1996) Variation in the feeding success of sperm whales: temporal scale, spatial scale and relationship to migrations. J Anim Ecol 65:429-438

Whitehead H (2001) Analysis of animal movement using opportunistic individual-identifications: application to sperm whales. Ecology 82:1417-1432

Whitehead H, Faucher A, Gowans S, McCarrey S (1997a) Status of the northern bottlenose whale, Hyperoodon ampullatus, in the Gully, Nova Scotia. Can Field-Nat 111:287-292

Whitehead H, Gowans S, Faucher A, McCarrey SW (1997b) Population analysis of northern bottlenose whales in the Gully, Nova Scotia. Mar Mamm Sci 13:173-185

Wilson B, Thompson PM, Hammond PS (1997) Habitat use by bottlenose dolphins: seasonal distribution and stratified movement patterns in the Moray Firth, Scotland. J Appl Ecol 34:1365-1374

Submitted: November 11, 2000; Accepted: February 20, 2001 Proofs received from author(s): December 21, 2001 